\title{
Penilaian Risiko Kualitatif Masuknya Rabies melalui Pergerakan Anjing dari Provinsi Jawa Barat ke Kota Surakarta
}

\section{Qualitative Risk Assessment on Rabies Entry through Dog Movement from West Java Province into Surakarta City}

\author{
Indri Permatasari ${ }^{* *}$, Bambang Sumiarto ${ }^{2}$, Heru Susetya ${ }^{2}$ \\ ${ }^{1}$ Direktorat Kesehatan Hewan Jakarta \\ ${ }^{2}$ Departemen Kesehatan Masyarakat Veteriner, Fakultas Kedokteran Hewan, \\ Universitas Gadjah Mada, Yogyakarta \\ *Email: iinlho99@gmail.com
}

Naskah diterima: 27 Juli 2020, direvisi: 6 November 2020, disetujui: 16 November 2020

\begin{abstract}
The high frequency of dog movement from rabies-infected areas to rabies-free areas still occurs in Indonesia. It is triggered by the emergence of rabies cases in free areas. This study aimed to conduct a qualitative risk assessment of rabies entry through dog movement from West Java Province into Surakarta City Central Java Province. Methods of the data collection in this research use primary data and secondary data. The primary data were obtained from interviews, questionnaires, observation, and expert opinion. Secondary data were obtained from literature, scientific publication, surveillance report, and unpublished document from the competent authorities. The results of the study showed that the release assessment is moderate with low uncertainty level, based on the incidence rate of rabies in animals 3,1\% in West Java Province in 2019. Exposure assessment is high with low uncertainty level, because of the high frequencies of the dog movement for consumption from West Java. The consequence assessment is high with low uncertainty level, because of the single impact of nationally significant categories. The results of the qualitative risk assessment of the entry of rabies into Surakarta City is high with low uncertainty level. The risk evaluation of risk assessment would consider the incidence rate of rabies in the area of origin and the frequency of daily movement of dog, which is an important issue of the risk of rabies entry.
\end{abstract}

Keywords: dogs; qualitative risk assessment; rabies; surakarta city

\begin{abstract}
Abstrak
Lalu lintas anjing dari daerah tertular rabies ke daerah bebas rabies masih terjadi di Indonesia. Hal ini menjadi salah satu pemicu terhadap munculnya kasus rabies di daerah bebas. Penelitian ini bertujuan untuk melakukan penilaian risiko kualitatif kemungkinan masuknya rabies melalui pergerakan anjing konsumsi dari Provinsi Jawa Barat ke Kota Surakarta, Provinsi Jawa Tengah. Metode pengumpulan data yang digunakan dalam penelitian ini menggunakan data primer dan data sekunder. Data primer diperoleh dari wawancara, kuesioner, pendapat pakar, dan observasi langsung di lapangan. Data sekunder diperoleh melalui kajian literatur, penelusuran publikasi ilmiah, dan dokumen dari instansi berwenang yang tidak dipublikasikan. Hasil penelitian menunjukkan bahwa penilaian pelepasan dari daerah asal anjing adalah "sedang" dengan ketidakpastian rendah. Tingkat kejadian rabies pada hewan di Provinsi Jawa Barat tahun 2019 sebesar 3,1\%. Penilaian pendedahan adalah "tinggi" dengan ketidakpastian rendah karena frekuensi pengiriman anjing konsumsi dari Provinsi Jawa Barat dilakukan setiap hari. Penilaian dampak adalah "tinggi" dengan ketidakpastian rendah karena ada dampak tunggal yang masuk dalam kategori signifikan di tingkat nasional. Kesimpulan dari penelitian ini adalah bahwa penilaian risiko kualitatif masuknya rabies ke Kota Surakarta adalah tinggi dengan ketidakpastian rendah. Evaluasi kemungkinan kualitatif dapat mempertimbangkan tingkat kejadian rabies daerah asal dan frekuensi pengiriman anjing konsumsi setiap hari yang merupakan masalah penting risiko masuknya rabies.
\end{abstract}

Kata kunci : anjing; kota Surakarta; penilaian risiko kualitatif; rabies. 


\section{Pendahuluan}

Rabies merupakan zoonosis utama di Indonesia yang masih menjadi problematika sampai saat ini. Sifat penyakit yang berakibat fatal menjadikan rabies dipertimbangkan sebagai emerging infectious disease yang paling mengancam (Salyer et al., 2017; Tarantola, 2017). Upaya pencegahan terhadap masuknya rabies ke daerah yang berstatus bebas harus terus dilakukan secara komprehensif dengan melibatkan seluruh pemangku kepentingan yang terlibat sesuai dengan kewenangannya. Persyaratan daerah bebas rabies yaitu tidak ada kasus positif baik pada hewan maupun manusia selama dua tahun terakhir (OIE, 2014). Provinsi Jawa Tengah merupakan provinsi bebas rabies yang ditetapkan dalam Keputusan Menteri Pertanian Nomor 892/Kpts/TN.560/9/1997. Namun demikian, tingginya lalu lintas anjing konsumsi ke Provinsi Jawa Tengah khususnya Kota Surakarta menjadi ancaman masuk dan tersebarnya rabies ke Kota Surakarta, mengingat anjing-anjing tersebut sebagian besar berasal Provinsi Jawa Barat yang merupakan daerah tertular rabies. Pemerintah Kota Surakarta belum memiliki kebijakan khusus yang mengatur lalulintas hewan penular rabies terutama anjing yang ditujukan untuk konsumsi. Peraturan yang dikeluarkan masih bersifat himbauan sehingga tidak memiliki kekuatan hukum dalam penerapan sanksi terhadap pelanggaran yang terjadi.

Kuliner yang menyajikan olahan daging anjing sudah lama ada di Kota Surakarta. Kebiasaan itu pun berlanjut dengan munculnya warung-warung makan masakan daging anjing di Kota Surakarta yang terus menjadi polemik hingga sekarang. Hal tersebut berimbas terhadap permintaan daging anjing sebagai bahan baku masakan. Provinsi Jawa Barat sebagai daerah tertular rabies berdasarkan Keputusan Menteri Pertanian Nomor. Menurut data Dinas Pertanian, Ketahanan Pangan, dan Perikanan Kota Surakarta tahun 2019, pengiriman anjing dilakukan setiap hari dengan jumlah ratarata 84 ekor. Kasus rabies baru pada anjing di daerah yang berstatus bebas rabies umumnya diketahui setelah adanya kasus rabies pada manusia. Oleh karena itu, kewaspadaan dini terhadap masuk dan menyebarnya rabies harus ditingkatkan. Penilaian risiko masuknya rabies sangat diperlukan sebagai bagian dari upaya pencegahan masuknya penyakit rabies di suatu wilayah. Penilaian risiko kualitatif didasarkan pada pengetahuan ilmiah, sistematis, logis, dan terstruktur untuk mencari faktor risiko yang relevan (Peeler et al., 2013).

Tujuan penelitian ini adalah melakukan penilaian risiko kualitatif terhadap kemungkinan masuknya rabies melalui pergerakan anjing konsumsi dari Jawa Barat ke Kota Surakarta dan mengidentifikasi jalur potensial dalam lalu lintas anjing ke Kota Surakarta, Provinsi Jawa Tengah. Hasil penelitian ini diharapkan dapat memberikan manfaat berupa: (1) penilaian risiko kualitatif terhadap kemungkinan masuknya rabies melalui peregerakan anjing konsumsi dari Jawa Barat ke Kota Surakarta, Provinsi Jawa Tengah, dan (2) Pengendalian dan penanggulangan rabies di Kota Surakarta pada khususnya dan Provinsi Jawa Tengah pada umumnya.

\section{Materi dan Metode}

Penelitian ini dilakukan menggunakan metode kualitatif. Sumber data yang digunakan meliputi data primer dan sekunder. Pengumpulan data primer diperoleh dari observasi langsung di lapangan, wawancara (in-depth interview), kuesioner, serta pengumpulan pendapat pakar. Pengambilan data sekunder dilakukan melalui penelusuran publikasi ilmiah dan data dari instansi berwenang yang tidak dipublikasi. Penelitian dilakukan di Dinas Pertanian, Ketahanan Pangan dan Perikanan Kota Surakarta Provinsi Jawa Tengah. Penelitian dilaksanakan pada bulan Januari sampai dengan April 2020.

Penilaian risiko kualitatif dilakukan dengan menggunakan standar analisis risiko importasi Office International des Epizooties/OIE (OIE, 2019). Penilaian likelihood/kemungkinan dilakukan dengan mengacu Biosecurity Import Risk Analysis Guidelines Australia (Department of Agriculture, 2016). Penilaian ketidakpastian (uncertainty) mengacu pada European Food Safety Authority (EFSA, 2018). Penilaian risiko dilakukan dengan melalui empat tahapan yaitu penilaian pelepasan (release assessment), penilaian pendedahan (exposure assessment), 
penilaian dampak (consequence assessment), dan perkiraan risiko (risk estimation).

Penilaian pelepasan didasarkan pada kemungkinan terjadinya infeksi pada hewan atau media pembawa penyakit di daerah asal. Kategori kemungkinan kualitatif (Tabel 1) dinilai melalui tahapan skenario kemungkinan pemasukan yang telah ditentukan. Kombinasi aturan penilaian diperlukan untuk menghitung seluruh kemungkinan terhadap skenario yang telah ditentukan (Tabel 2).

Penilaian pendedahan didasarkan pada kemungkinan kontak melalui anjing konsumsi yang terinfeksi rabies sehingga menyebabkan terjadinya penularan baik pada manusia, anjing lokal/setempat, dan HPR rentan lainnya. Penghitungan penilaian pendedahan menggunakan enam kategori peluang sebagaimana penilaian kemungkinan pada penilaian pelepasan. Penilaian pendedahan ganda terjadi apabila titik akhir pendedahan pada hewan rentan atau manusia yang terinfeksi berasal dari dua jalur atau lebih pada alur tapak yang berbeda (Tabel 3).

Penilaian dampak dilakukan berdasarkan pada pertimbangan setiap dampak yang terjadi karena masuknya rabies ke Kota Surakarta. Kriteria penilaian dampak dibagi menjadi dampak langsung dan dampak tidak langung. Penilaian dampak berdasarkan cakupan wilayah dari tingkat peternakan/desa hingga tingkat nasional yang dibagi dalam tujuh skala kualitatif (Tabel 4). Dampak keseluruhan secara nasional dihubungkan dengan dampak langsung dan tidak langsung yang diperkirakan pada skala kualitatif.

Tabel 1. Kategori kemungkinan kualitatif dan penafsirannya (Department of Agriculture Australia, 2016)

\begin{tabular}{ll}
\hline \multicolumn{1}{c}{ Kategori kemungkinan } & \multicolumn{1}{c}{ Penafsiran } \\
\hline Tinggi (High) & Kejadiannya sangat mungkin terjadi \\
Sedang (Moderate) & Kejadiannya kemungkinan terjadi \\
Rendah (Low) & Kejadiannya kemungkinan tidak terjadi \\
Sangat rendah (Very Low) & Kejadiannya sangat mungkin tidak terjadi \\
Amat sangat rendah (Extremely Low) & Kejadiannya amat sangat tidak mungkin terjadi \\
Dapat diabaikan (Negligible) & Kejadiannya hampir tidak pernah terjadi \\
\hline
\end{tabular}

Tabel 2. Matriks aturan kombinasi penggambaran likelihood (Department of Agriculture, 2016)

\begin{tabular}{lcccccc}
\hline & \multicolumn{7}{c}{ Likelihood 2 } \\
\cline { 2 - 6 } Kemungkinan & High & moderate & low & Verylow & Extremely low & Negligible \\
\hline High & $\mathrm{H}$ & $\mathrm{M}$ & $\mathrm{L}$ & $\mathrm{VL}$ & $\mathrm{EL}$ & $\mathrm{N}$ \\
Moderate & $\mathrm{M}$ & $\mathrm{L}$ & $\mathrm{L}$ & $\mathrm{VL}$ & $\mathrm{EL}$ & $\mathrm{N}$ \\
Low & $\mathrm{L}$ & $\mathrm{L}$ & $\mathrm{VL}$ & $\mathrm{VL}$ & $\mathrm{EL}$ & $\mathrm{N}$ \\
verylow & $\mathrm{VL}$ & $\mathrm{VL}$ & $\mathrm{VL}$ & $\mathrm{EL}$ & $\mathrm{EL}$ & $\mathrm{N}$ \\
extremely low & $\mathrm{EL}$ & $\mathrm{EL}$ & $\mathrm{EL}$ & $\mathrm{EL}$ & $\mathrm{N}$ & $\mathrm{N}$ \\
Negligible & $\mathrm{N}$ & $\mathrm{N}$ & $\mathrm{N}$ & $\mathrm{N}$ & $\mathrm{N}$ & $\mathrm{N}$ \\
\hline
\end{tabular}

Keterangan: $\mathrm{H}=$ high (tinggi); Moderate (sedang); Low (rendah); $\mathrm{VL}=$ very low (sangat rendah); $\mathrm{EL}=$ extremely low (amat sangat rendah); $\mathrm{N}=$ negligible (dapat diabaikan).

Tabel 3. Penilaian pendedahan ganda (Department of Agriculture Australia, 2016)

\begin{tabular}{lc}
\multicolumn{1}{c}{ Nilai Kemungkinan } & Risiko Keseluruhan \\
\hline Salah satu risiko parsial tinggi & Tinggi \\
Lebih dari satu risiko parsial sedang & Tinggi \\
Salah satu risiko parsial sedang dan risiko parsial yang lainnya adalah rendah & Tinggi \\
Ada satu risiko parsial sedang dan risiko parsial yang lainnya tidak sedang & Sedang \\
Semua risiko parsial rendah & Sedang \\
Satu atau lebih risiko parsial rendah & Rendah \\
Semua risiko parsial sangat rendah & Rendah \\
Satu atau lebih risiko parsial sangat rendah & Sangat rendah \\
Semua risiko parsial ekstrim rendah & Sangat rendah \\
Satu atau lebih risiko parsial amat sangat rendah & Amat sangat rendah \\
Semua risiko parsial dapat diabaikan & Dapat diabaikan \\
\hline
\end{tabular}


Tabel 4. Kategori penilaian dampak berdasarkan cakupan wilayah (Department of Agriculture Australia, 2009)

\begin{tabular}{cl}
\hline Kategori & \multicolumn{1}{c}{ Deskripsi } \\
\hline G & Dampak bersifat sangat signifikan di tingkat nasional \\
F & Dampak bersifat signifikan di tingkat nasional \\
E & Dampak bersifat cukup signifikan di tingkat nasional \\
D & Dampak bersifat cukup signifikan di tingkat negara bagian/provinsi \\
C & Dampak bersifat cukup signifikan di tingkat kabupaten/kota/distrik \\
B & Dampak bersifat cukup signifikan di tingkat lokal (peternakan/desa) \\
A & Dampak bersifat sangat minor atau dapat diabaikan \\
\hline
\end{tabular}

Tabel 5. Matriks perkiraan risiko (Department of Agriculture Australia, 2016)

\begin{tabular}{|c|c|c|c|c|c|c|c|}
\hline \multirow{8}{*}{ 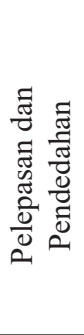 } & \multirow{3}{*}{$\begin{array}{l}\text { Kemungkinan } \\
\text { High }\end{array}$} & \multicolumn{6}{|c|}{ Dampak } \\
\hline & & negligible risk & very low risk & low risk & moderate risk & high risk & extreme impact \\
\hline & & NR & VLR & LR & $\mathrm{MR}$ & HR & ER \\
\hline & Moderate & NR & VLR & LR & MR & HR & ER \\
\hline & Low & NR & NR & VLR & LR & MR & HR \\
\hline & very low & NR & NR & NR & VLR & LR & MR \\
\hline & extremely low & NR & NR & NR & NR & VLR & LR \\
\hline & Negligible & NR & NR & NR & NR & NR & VLR \\
\hline
\end{tabular}

Keterangan: $\mathrm{HR}=$ high risk (risiko tinggi); $\mathrm{MR}=$ Moderate risk (risiko sedang); $\mathrm{LR}=$ Low risk (risiko rendah); $\mathrm{VLR}=$ very low risk (risiko sangat rendah); $\mathrm{ER}=$ extremely low risk(risiko amat sangat rendah); $\mathrm{NR=negligible} \mathrm{risk} \mathrm{(risiko} \mathrm{dapat}$ diabaikan

Perkiraan Risiko ditentukan melalui penggabungan hasil antara penilaian pelepasan dan pendedahan dengan hasil penilaian dampak. Perkiraan risiko merupakan tahap terakhir dan menjadi kesimpulan pada penilaian risiko. Matriks perkiraan risiko disajikan pada Tabel 5.

Ketidakpastian menunjukkan adanya sebaran nilai dari variabel yang disebabkan karena sedikitnya informasi mengenai nilai-nilai kemungkinan. Nilai ketidakpastian dinyatakan secara kualitatif dalam tiga kategori, yaitu rendah jika didukung oleh data yang lengkap, bukti kuat oleh berbagai referensi dengan observasi terstruktur. Ketidakpastian sedang jika ada beberapa data yang tidak lengkap, bukti disajikan pada referensi yang terbatas, dan kesimpulan penulis bervariasi satu sama lain. Ketidakpastian tinggi apabila tidak tersedia data dan bukti tidak tersedia di referensi tetapi pada laporan yang tidak terpublikasi (EFSA, 2018).

\section{Hasil dan Pembahasan}

\section{Penilaian Pelepasan (Release Assessment)}

Alur tapak penilaian pelepasan rabies ke Kota Surakarta adalah melalui lalu lintas anjing dari Provinsi Jawa Barat. Jalur potensial masuknya rabies adalah melalui pergerakan pemasukan anjing konsumsi dari Provinsi Jawa

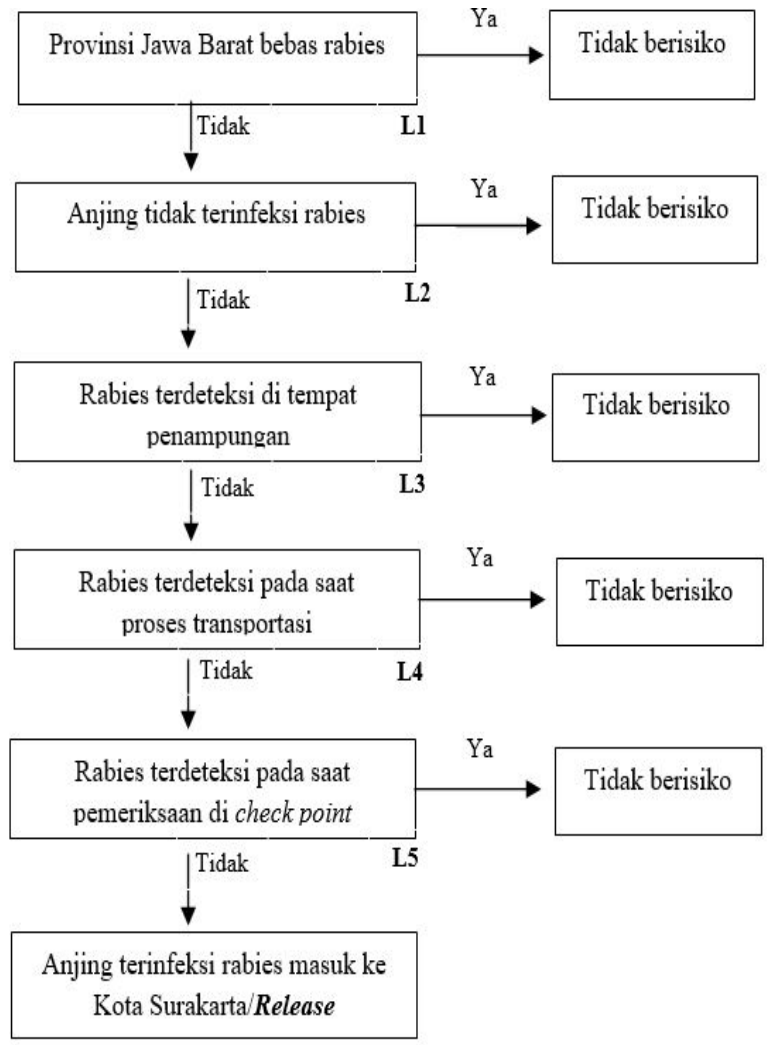

Gambar 1. Alur tapak penilaian pelepasan masuknya rabies melalui anjing konsumsi dari Provinsi Jawa Barat ke Kota Surakarta

Barat. Informasi mengenai alur tapak penilaian pelepasan rabies ke Kota Surakarta disajikan dalam Gambar 1.

Provinsi Jawa Barat merupakan daerah tertular rabies yang dinyatakan dalam Surat 
Keputusan Menteri Pertanian Nomer 3600/ Kpts/PD.640/10/2009 tentang Pernyataan Berjangkitnya Penyakit Anjing Gila (Rabies) di Kabupaten Garut, Sukabumi, Tasikmalaya, Cianjur, dan Kota Sukabumi. Berdasarkan hasil wawancara dengan responden, baik pedagang pengumpul maupun pemilik tempat pemotongan anjing di Kota Surakarta, menyatakan bahwa mereka membeli anjing yang berasal dari Kabupaten Tasikmalaya, Kabupaten Garut, dan Kabupaten Sukabumi. Anjing yang diperdagangkan untuk konsumsi sebagian besar berasal dari anjing liar yang menghuni wilayah hutan dan pegunungan di sekitar kabupatenkabupaten tersebut. Anjing kemudian diburu dan ditangkap untuk dikumpulkan di tempat pengumpulan sementara dalam waktu 1-7 hari sebelum dijual (Safitri, 2015). Anjing konsumsi yang diperdagangkan tidak divaksinasi rabies.

Kasus positif rabies di Provinsi Jawa Barat tidak hanya terjadi pada hewan tetapi juga pada manusia. Kasus Gigitan Hewan Penular Rabies (GHPR) di Provinsi Jawa Barat terjadi hingga tahun 2016. Dinas Kesehatan Provinsi Jawa Barat menyebutkan, sebanyak 664 kasus dilaporkan pada tahun 2016 yang mengakibatkan 1 orang korban meninggal dunia. Kasus positif rabies pada anjing di Provinsi Jawa Barat tahun 2019 sebanyak 2 kasus, semua kasus terjadi di Kabupaten Bandung Barat.

Rabies dapat tetap bersirkulasi di daerah endemis di Asia dan Afrika dengan rata-rata tingkat densitas populasi anjing 4,5 ekor $/ \mathrm{km}^{2}$ (Lembo et al., 2010). Menurut Dibia (2014), secara epidemiologi hanya dibutuhkan satu ekor anjing penderita rabies yang masuk ke daerah bebas rabies secara historis dengan kepadatan populasi anjing yang tinggi dan berkeliaran sudah cukup untuk menimbulkan wabah. Hasil pengujian enzyme-linked immunosorbent assay (ELISA) yang dilakukan Balai Veteriner Subang pada kegiatan surveilans di Kabupaten Bandung Barat pada tahun 2016 memperlihatkan tingkat kekebalan protektif anjing pasca vaksinasi sebesar 53\% dengan cakupan vaksinasi rabies 64\%. Angka tersebut belum memenuhi cakupan vaksinasi minimal yang direkomendasikan oleh OIE yaitu minimal $70 \%$ dari populasi (OIE, 2014). Rendahnya tingkat kekebalan antibodi protektif merupakan salah satu sumber potensial dalam penyebaran virus rabies. Faktor yang menyebabkan tingkat kekebalan protektif rendah antara lain recording yang tidak jelas. Faktor lain adalah tingkat pengetahuan dan partisipasi pemilik anjing yang rendah terutama di daerah pedesaan (Utami et al., 2012).

Rentang masa inkubasi virus rabies bervariasi, mulai dari 5 hari hingga beberapa tahun. Pada umumnya terjadi selama 2-3 bulan, masa inkubasi lebih dari 1 tahun jarang terjadi (OIE, 2014). Kasus rabies di Flores terjadi akibat masuknya anjing-anjing dalam masa inkubasi dari Pulau Buton, Sulawesi Tenggara yang dibawa oleh nelayan tradisional yang dibuktikan melalui analisis filogenetik virus rabies (Susetya et al., 2008). Beberapa penelitian juga melaporkan bahwa masuknya rabies ke suatu wilayah terjadi karena adanya pergerakan hewan-hewan peka rabies akibat intervensi manusia (Mailles et al., 2011; Van Rijckevorsel et al., 2012).

Penilaian risiko pelepasan rabies diperoleh dengan menghitung keseluruhan nilai kemungkinan/likelihood yaitu kemungkinan Provinsi Jawa Barat tidak bebas rabies (L1), kemungkinan anjing tidak terinfeksi (L2), kemungkinan anjing terinfeksi rabies tidak terdeteksi di tempat penampungan (L3), kemungkinan anjing terinfeksi rabies tidak terdeteksi selama transportasi (L4), dan kemungkinan anjing terinfeksi rabies tidak terdeteksi di pos pemeriksaan lalu lintas hewan/check point (L5). Penilaian pelepasan rabies ke Kota Surakarta melalui pergerakan anjing konsumsi dari Provinsi Jawa Barat adalah sedang. Penilaian pelepasan mempunyai tingkat ketidakpastian rendah karena didukung oleh data yang lengkap, dengan melakukan wawancara, penyebaran kuesioner ke responden, serta observasi langsung di lapangan. Data sekunder diperoleh dari dokumen dan laporan Instansi yang berwenang yang tidak dipublikasikan. Selain itu juga dilakukan studi literatur dari berbagai referensi (EFSA, 2018). Penilaian untuk masing-masing tahapan beserta kemungkinannya disajikan pada Tabel 6 .

\section{Penilaian Pendedahan (Exposure Assesss- ment)}

Penilaian pendedahan dilakukan terhadap kemungkinan terjadinya penularan rabies dari 
Tabel 6. Kemungkinan penilaian pelepasan masuknya rabies ke Kota Surakarta melalui anjing konsumsi dari Provinsi Jawa Barat

\begin{tabular}{|c|c|c|c|c|}
\hline Node & Deskripsi & Kemungkinan & $\begin{array}{c}\text { Tingkat } \\
\text { Ketidakpastian }\end{array}$ & Sumber data \\
\hline $\begin{array}{l}\text { kemungkinan Provinsi } \\
\text { Jawa Barat tidak bebas } \\
\text { rabies }\end{array}$ & $\begin{array}{l}\text { Provinsi Jawa Barat berstatus sebagai } \\
\text { daerah tertular rabies }\end{array}$ & Tinggi (L1) & Rendah & $\begin{array}{l}\text { Kepmentan No.3600/ } \\
\text { Kpts/PD.640/10/2009 }\end{array}$ \\
\hline $\begin{array}{l}\text { kemungkinan anjing tidak } \\
\text { terinfeksi }\end{array}$ & $\begin{array}{l}\text { Prevalensi rabies pada anjing di wilayah } \\
\text { kerja Balai Veteriner Subang adalah } \\
3,10 \%(10 / 322) \\
\text { Kasus GHPR di Provinsi Jawa Barat } \\
\text { yang dilaporkan pada periode 2016- } \\
2019 \text { sebesar } 1359 \text { kasus } \\
\text { Terdapat } 2 \text { kasus positif rabies pada } \\
\text { anjing pada tahun } 2019 \text { di Kabupaten } \\
\text { Bandung Barat }\end{array}$ & Tinggi (L2) & Rendah & $\begin{array}{l}\text { BVet Subang (2020) } \\
\text { Dinkes Jabar (2019) } \\
\text { BVet Subang, DKPP } \\
\text { Prov Jabar (2020) }\end{array}$ \\
\hline $\begin{array}{l}\text { kemungkinan anjing } \\
\text { terinfeksi rabies tidak } \\
\text { terdeteksi di tempat } \\
\text { penampungan }\end{array}$ & $\begin{array}{l}\text { Tingkat kekebalan protektif anjing } \\
\text { pasca vaksinasi 53\%, cakupan } \\
\text { vaksinasi rabies 64\% pada tahun } 2016 \\
\text { di Kabupaten Bandung Barat. Tingkat } \\
\text { kekebalan protektif pada anjing yang } \\
\text { dilalulintaskan melalui pelabuhan } \\
\text { Merak hanya sekitar 21\% } \\
\text { Anjing ditempatkan dalam kandang } \\
\text { yang sama, dilaporkan pernah terjadi } \\
\text { pertengkaran. Anjing tidak pernah } \\
\text { divaksin selama di penampungan }\end{array}$ & Tinggi (L3) & Rendah & $\begin{array}{l}\text { BVet Subang (2020) } \\
\text { BKP Kelas II Cilegon } \\
(2020) \\
\text { Wawancara, } \\
\text { Safitri (2015) }\end{array}$ \\
\hline
\end{tabular}

anjing konsumsi terinfeksi yang berasal dari Provinsi Jawa Barat, sehingga virus mendedah pada manusia dan hewan rentan lainnya akibat pergerakan pemasukan anjing konsumsi ke Kota Surakarta. Alur tapak pendedahan masuknya rabies ke Kota Surakarta tersaji pada Gambar 2.
Kemungkinan anjing dan manusia tertular rabies dari pergerakan pemasukan anjing konsumsi yang berasal dari Provinsi Jawa Barat diperoleh dengan melakukan observasi langsung, penyebaran kuesioner, dan wawancara terhadap pekerja di tempat pemotongan, masyarakat yang

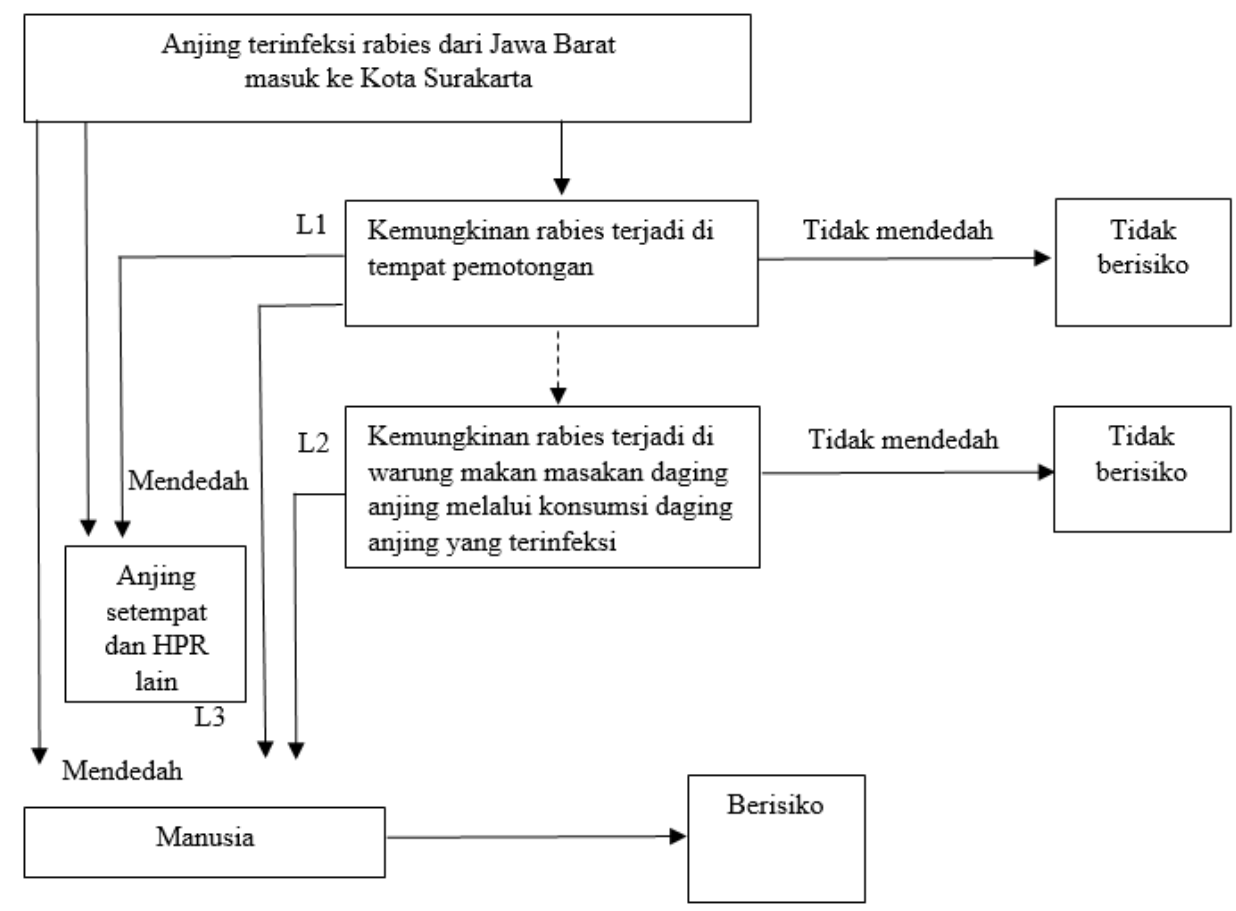

Gambar 2. Alur tapak penilaian pendedahan masuknya rabies melalui anjing konsumsi dari Provinsi Jawa Barat ke Kota Surakarta 
Tabel 7. Kemungkinan penilaian pendedahan rabies melalui pemasukan anjing konsumsi dari Provinsi Jawa Barat ke Kota Surakarta

\begin{tabular}{|c|c|c|c|c|}
\hline Node & Deskripsi & $\begin{array}{c}\text { Kemungkinan/ } \\
\text { likelihood }\end{array}$ & $\begin{array}{c}\text { Tingkat } \\
\text { ketidakpastian }\end{array}$ & Sumber data \\
\hline $\begin{array}{l}\text { Kemungkinan anjing } \\
\text { konsumsi yang terdedah } \\
\text { rabies kontak dengan } \\
\text { manusia di tempat } \\
\text { pemotongan }\end{array}$ & $\begin{array}{l}\text { Anjing berasal dari daerah } \\
\text { tertular. Masa inkubasi rabies } \\
\text { bervariasi } 10 \text { hari- } 8 \text { minggu. } \\
\text { Pekerja tidak memakai alat } \\
\text { pelindung diri saat pemotongan. }\end{array}$ & Tinggi (L1) & Rendah & $\begin{array}{l}\text { OIE (2014) } \\
\text { Prakitt et al. (2013), } \\
\text { observasi, kuesioner, } \\
\text { dan wawancara }\end{array}$ \\
\hline $\begin{array}{l}\text { Kemungkinan anjing } \\
\text { setempat dan HPR rentan } \\
\text { lain terdedah anjing } \\
\text { konsumsi yang terdedah } \\
\text { rabies }\end{array}$ & $\begin{array}{l}\text { Anjing berasal dari daerah } \\
\text { tertular. Anjing lokal ada yang } \\
\text { berkeliaran di sekitar lokasi. } \\
\text { Anjing liar berkontribusi } \\
\text { terhadap rabies hingga } 81 \%\end{array}$ & Sedang (L2) & Rendah & $\begin{array}{l}\text { Anonim (2017), } \\
\text { OIE (2014), Putra } \\
\text { (2011), observasi dan } \\
\text { wawancara }\end{array}$ \\
\hline $\begin{array}{l}\text { Kemungkinan manusia } \\
\text { tertular rabies karena } \\
\text { konsumsi masakan daging } \\
\text { anjing yang terinfeksi }\end{array}$ & $\begin{array}{l}\text { Virus rabies akan mati pada } \\
\text { suhu } 50^{\circ} \mathrm{C} \text { selama } 1 \text { jam }\end{array}$ & $\begin{array}{l}\text { Sangat rendah } \\
\text { (L3) }\end{array}$ & Rendah & $\begin{array}{l}\text { Jawetz et al. (2008), } \\
\text { observasi, wawancara }\end{array}$ \\
\hline Penilaian pendedahan & L1 x L2 x L3 & Tinggi & Rendah & \\
\hline
\end{tabular}

tinggal di sekitar lokasi pemotongan, dan pelaku usaha warung makan masakan daging anjing di Kota Surakarta. Nilai kemungkinan pendedahan rabies ke Kota Surakarta dapat dilihat pada Tabel 7.

Rabies bisa terdedah melalui proses penyiapan daging anjing melalui kontak langsung dengan sekresi hewan tanpa alat perlindungan diri. Anjing konsumsi yang tidak divaksin dan berasal dari daerah tertular rabies memiliki potensi menularkan rabies (Wertheim et al., 2009). Menurut Prakit et al. (2013), mengonsumsi daging anjing yang terinfeksi rabies dapat menimbulkan risiko penularan jika daging tidak dimasak dengan baik, meski demikian virus rabies akan mati pada suhu $50^{\circ} \mathrm{C}$ selama 1 jam (Jawetz et al., 2008).

Hasil penilaian pendedahan secara keseluruhan untuk Kota Surakarta adalah tinggi. Hal ini berdasarkan pada Tabel 3, yang menyebutkan jika salah satu risiko parsial tinggi maka risiko secara keseluruhan adalah tinggi dengan tingkat ketidakpastian rendah. Penilaian pendedahan mempunyai tingkat ketidakpastian rendah karena didukung oleh data yang lengkap, dengan melakukan wawancara, penyebaran kuesioner ke responden yaitu petugas Dinas Pertanian, Ketahanan Pangan, dan Perikanan Kota Surakarta, pedagang pengumpul anjing, pekerja di tempat pemotongan anjing, dan pedagang masakan daging anjing serta observasi langsung di lapangan yang dilakukan secara terstruktur. Data sekunder diperoleh dari dokumen dan laporan instansi yang berwenang yang tidak dipublikasikan (EFSA, 2018).

Jalur potensial masuknya rabies ke Kota Surakarta adalah melalui pergerakan anjing konsumsi dari Provinsi Jawa Barat yang dilalulintaskan melalui jalur darat. Alat transportasi yang digunakan adalah menggunakan truk bak terbuka yang ditutup dengan terpal. Transportasi pada umumnya dilakukan pada malam hari. Akses yang dilewati melalui jalan utama yaitu jalur selatan Pulau Jawa. Pembangunan jalan tol di jalur pantai utara tidak banyak dipilih oleh pedagang pengepul anjing karena harus mengeluarkan biaya tambahan meskipun jarak tempuh menjadi lebih singkat.

\section{Penilaian Dampak (Consequence Assessment)}

Dampak langsung masuknya rabies ke Kota Surakarta akibat pergerakan pemasukan anjing konsumsi dari Provinsi Jawa Barat adalah timbulnya wabah rabies pada anjing dan HPR rentan lainnya yang akan menjadi reservoir dan menularkan rabies ke manusia. Dampak langsung yaitu terjadi penularan rabies yang berpengaruh pada kesehatan hewan dan manusia. Dampak pada kesehatan hewan dinilai dengan skala D, yaitu dampak cukup signifikan di tingkat provinsi. Penilaian ini diperoleh mengingat Kota Surakarta yang strategis di Provinsi Jawa Tengah. Dampak kesehatan hewan dinilai signifikan di tingkat provinsi karena anjing yang masuk dari daerah endemis 
ke daerah bebas sangat berisiko menularkan rabies melalui kontak dengan anjing lokal yang berkeliaran serta hewan penular ranbies lainnya (Dibia et al., 2014). Dampak pada kesehatan manusia dinilai dengan skala $\mathrm{F}$, yang berarti signifikan di tingkat nasional. Penilaian ini berdasarkan pertimbangan bahwa rabies merupakan zoonosis dan bersifat fatal dengan tingkat kematian mencapai 99,9\% setelah muncul gejala klinis (Anonim, 2015; OIE, 2014). Dampak tidak langsung meliputi dampak ekonomi yang dinilai dalam skala E yaitu cukup signifikan di tingkat nasional. Biaya kesehatan masyarakat merupakan komponen biaya terbesar dalam penanganan rabies (Batan et al., 2014). Dampak sosial berupa keresahan masyarakat karena wabah rabies dan penurunan wisatawan dinilai dalam skala D, yang artinya bersifat cukup signifikan di tingkat provinsi. Kota Surakarta mengandalkan industri pariwisata sebagai salah satu andalan yang berkontribusi besar pada pendapatan daerah. Berdasarkan data Badan Pusat Statistik Kota Surakarta (2020), turis yang berkunjung ke Kota Surakarta sebanyak 3.549.504 wisatawan nusantara dan 13.047 wisatawan mancanegara. Jumlah wisatawan diperkirakan menurun drastis jika terjadi wabah rabies di Kota Surakarta sehingga berdampak nyata terhadap perekonomian para pelaku industri pariwisata. Kecemasan dan keresahan masyarakat juga tidak bisa dihindari karena rabies adalah zoonosis yang bisa mengakibatkan kematian pada manusia. Penilaian dampak keseluruhan adalah tinggi karena adanya dampak tunggal yang bersifat signifikan dalam skala nasional.

\section{Perkiraan Risiko (Risk Estimation)}

Perkiraan risiko dinilai dengan menggunakan matriks perkiraan risiko yang mengacu pada risk analysis framework Australia (Tabel 4). Berdasarkan pada hasil penghitungan penilaian pelepasan, penilaian pendedahan, dan penilaian dampak yang telah dilakukan sebelumnya. Perkiraan risiko $=($ sedang $\mathrm{x}$ tinggi $) \times$ tinggi $=$ sedang $\mathrm{x}$ tinggi $=$ tinggi. Berdasarkan hasil perhitungan dapat dilihat bahwa perkiraan risiko adalah tinggi dengan tingkat ketidapastian rendah.

\section{Kesimpulan}

Penilaian risiko masuknya rabies ke Kota Surakarta melalui pemasukan anjing dari Provinsi Jawa Barat adalah tinggi, yang artinya sangat mungkin terjadi. Penilaian tersebut merupakan hasil dari penilaian pelepasan sedang, penilaian pendedahan tinggi, dan penilaian dampak tinggi. Semua penilaian memiliki tingkat ketidakpastian rendah. Perdagangan dan konsumsi daging anjing merupakan risiko terhadap penularan dan penyebaran penyakit rabies. Jalur potensial masuknya rabies ke Kota Surakarta adalah melalui pemasukan anjing konsumsi yang ditransportasikan melalui jalur darat dari Provinsi Jawa Barat yang merupakan daerah tertular rabies.

\section{Daftar Pustaka}

Anonim (2015) Pedoman pengendalian dan penanggulangan rabies. Direktorat Kesehatan Hewan. Direktorat Jenderal Peternakan dan Kesehatan Hewan. Kementerian Pertanian, Jakarta.

Badan Pusat Statistika (2020) Jumlah pengunjung daya tarik wisata di Kota Surakarta. Retrieved April 23, 2020. from https://surakartakota.bps.go.id/ statictable/2020/05/22/235/jumlahpengunjung-daya-tarik-wisata-di-kotasurakarta-2019.html.

Batan. I. W., Lestyorini. Y., Milfa. S., Iffandi. C., Nasution. A.A., Faiziah. N., Rasdinasyah., Herbert., Palgunadi. N. W. L., Suatha. I. K. and Kardena. I. M. (2014) Economic losses of rabies in Bali. J. Vet.15(4): 515522.

Department of Agriculture Australia (2016) Biosecurity Import Risk Analysis Guidelines 2016 Managing biosecurity risk for imports into Australia. Retrieved August 23, 2019, from https://www.agriculture. gov.au/biosecurity/risk-analysis/ guidelines.

Department of Agriculture Australia (2009) Risk analysis framework. Retrieved September 1, 2019, from http://www.ogtr.gov.au/ internet/ogtr/publishing.nsf/Content/ raffinal5-toc/\$FILE/raffinal5_2.pdf. 
Dibia, I. N., Diarmita, K, Dartini N. L. and Arsani, N. M. (2014) Analisis kualitatif risiko penyebaran rabies dari Bali. Bul. Vet. BBV Denpasar. 26 (84): 35-45.

EuropeanFood SafetyAuthority(2018)Guidance on Uncertainty. Retrieved May 16, 2019, from https://efsa.onlinelibrary.wiley.com/ doi/full/10.2903/j.efsa.2018.5123.

Jawetz, E., Melnick, J. L., Adelberg, E. A. (2008) Medical Microbiology, 25th ed. New York (US): Mc Graw Hill.

Lembo, T., Hampson, K., Kaare, M. T., Ernest, E., Knobel, D., Kazwala, R. R., Haydon, D. T., and Cleaveland. (2010). The feasibility of canine rabies elimination in Africa: dispelling doubts with data. Plos Neglected Tropical Diseases. 4(2): 1-9.

Mailles, A., Boisseleau, D., Dacheux, L., Michaiewisez, C., Gloaguen, C., Poncon, N., Bourhy, H., Callon, H., Vaillant, V., Dabosville, L., and Houssine, P. M. (2011) Rabid dog illegally imported to France from Marocco, August 2011. Euro Surveill. 16(33):1-3.

Office International des Epizooties (2014) World Organization for Animal Health. Rabies Portal. Retrieved May 10, 2019, from $h t t p: / / w w w . o i e . i n t / a n i m a l-h e a l t h-i n-$ the-world/rabies-portal/.

Office International des Epizooties (2019) World Organization for Animal Health. Risk Analysis Chapter 2.1 Import Risk Analysis. Retrieved May 10, 2019, from https://www.oie.int/fileadmin/Home/eng/ Health_standards/tahc/current/chapitre_ import_risk_analysis.pdf.

Peeler, E. J., Reese, R. A and Thrush, M. A. (2013) Animal disease import risk analysis - a review of current methods and practice. Transbound Emerg Dis. 62 (2015): 480-490.

Van Rijckevorsel, G. F., Swaan, C. M., Van den Bergh, J. P., Goorhuis, D., Baayen, L., Timen, and Van de Hoek (2012) Rabid puppy infected in Netherland from Marocco via Spain, February 2012. Euro Surveilance. 17(12): 1-2.
Prakit, S., Wongplugsasoong, W., Tranprasert, S., Sithi, W., Thamiganont, J., Insea, T., Tooraroap, S., Bootrach, S. and Rungreung, H. (2013) Investigation on a dog rabies case and rabid dog meat consumption, Nakhon Phanom Province, Thailand 2011. OSIRJ. 6(1): 6-12.

Putra, A. A. G. (2011) Epidemiologi rabies di Bali, analisis kasus rabies pada semi free-ranging dog dan signifikansinya dalam siklus penularan rabies dengan pendekatan ekosistem. Buletin Veteriner BBV Denpasar. 23(78): 45-55.

Safitri, V. (2015) Penilaian Risiko Kualitatif Pemasukan Virus Rabies dari Kabupaten Sukabumi ke DKI Jakarta Melalui Anjing. tesis. Bogor: Institut Pertanian Bogor.

Salyer, S. J. (2017) Prioritizing Zoonoses for Global Health Capacity BuildingThemes from One Health Zoonotic Disease Workshops in 7 Countries, 20142016. Journal of Emerg Infect Dis. PMC. 23(Suppl 1): S55-S64.

Susetya, H., Sugiyama, M., Inagaki, A., Ito, N., Mudiarto, G. and Minamoto, N. (2008) Molecular epidemiology of rabies in Indonesia. Virus Research. 135 (2008): 144-149.

Tarantola, A. (2017) Four Thousand Years of Concepts Relating to Rabies in Animals and Humans, Its Prevention and Its Cure. J. of Trop.Med. Infect. Dis. PMC. 2(2):15.

Utami. S. and Sumiarto. B. (2012) Tingkat dan faktor risiko kekebalan protektif terhadap rabies pada anjing di Kota Makassar. JSV . 13(1): 77-85.

Wertheim H. F. L., Nguyen T. Q., Nguyen, K. A. T., Jong, M. D., Taylor, W. R. J., Le, T. V., Nguyen, H. H., Nguyen, H. T. H., Farrar, J., Horby, P. and Nguyen, H. D. (2009) Furious rabies after an atypical exposure. J. P. Med. 6(3):1-5. 